\title{
Population-based studies reveal differences in the allelic frequencies of two functionally significant human interleukin-4 receptor polymorphisms in several ethnic groups
}

Michele Caggana, $S c D^{1}$ Kimberly Walker ${ }^{1}$ Andrew A Reilly, $P h D^{2}$, James $M$ Conroy, $P h D^{1}$, Salvatore Duval, and Anne C. Walsh, $P h D^{3}$

\begin{abstract}
Purpose: The presence of functionally significant human interleukin-4 receptor sequence variants, GIn551Arg and lle50Val, was examined in four anonymous New York State populations defined by ethnic origin. These variants were studied because they are associated with atopy or atopic asthma whose prevalence varies in different populations. Methods: PCR/RFLP (lle50Val) and PCR/allele-specific oligonucleotide hybridization (Gln551Arg) assays were developed to detect both polymorphisms in 855 newborn screening specimens. Results: Arg551 was most frequently found in Blacks (allele frequency of 68\%). However, the lle50 allele was most common in Whites (allele frequency, 87\%). Significantly more Blacks had chromosomes bearing both of the "enhanced signaling" variants (Ile50/Arg551). Conclusions: Enhanced IL-4R signaling is associated with increased IgE production (atopy). Therefore, our data suggest that the African American population may be at increased risk for diseases, including asthma, which are associated with atopy. These data also emphasize the importance of determining the frequencies of single nucleotide polymorphisms in different populations before drawing conclusions from allele association studies, since the background allele frequencies may be disparate between different populations.
\end{abstract} Genetics in Medicine, 1999:1(6):267-271.

Key Words: population allele frequencies, newborn screening dried blood specimens, mutation detection, interleukin-4 receptor

Atopy is a common clinical syndrome characterized by heightened IgE production upon exposure to common environmental antigens. It is associated with the development of allergic disorders including asthma. Genetic predisposition toward the development of atopy and asthma appears to be determined by multiple genetic loci. ${ }^{1-5}$ Among the candidate atopy susceptibility genes are those encoding interleukin-4 (IL-4) and the IL-4-binding subunit (IL-4R $\alpha$ ) of the interleukin-4 receptor (IL-4R).1,6-10 IL-4 is thought to play a critical role in the development of atopy and allergic diseases through its regulation of the induction of $\mathrm{T}_{\mathrm{H}} 2$ phenotype in allergenspecific helper $\mathrm{T}$ cells, and the induction of IgE synthesis by allergen-specific B cells. IL-4 is produced by activated T cells, mast cells, basophils and thymocytes, and mediates its pleiotropic effects on target cells by signal transduction through

From the 'Laboratory' of Molecular Genetic Epidemiology', 'Computational Molecular Biology and Statistics Core', and 'Laboratory' of Clinicul and Experimental Endocrinology' and Immunology, New' York State Departinent of Health, Wadsworth Center. Allany, New York Supported by the New York State Departme'nt of Health.

Dr. Michele Caggana. Wadsworth Couter/Empire State Plaza, New York Stute Department of Health, Madison Avenue, P.O. Box 509, Albamy, NY'12201-0509.

Received: May 4, 1999

Accepted: July 29, 1999.
IL-4 receptors, which are expressed on the surface of numerous cell types. In cells of hematopoietic origin, the IL- $4 \mathrm{R}$ is composed of the IL-4-binding subunit encoded by $I L-4 R \alpha$ and the common $\gamma$ subunit $\left(\gamma_{c}\right)$ shared by a number of other cytokine receptors. In cells of nonhematopoietic origin, the IL- $4 \mathrm{R}$ is thought to be composed of the IL- $4 \mathrm{R} \alpha$ and the IL-13R $\alpha$ l subunits. ${ }^{11,12}$

Mice deficient in either IL- 4 or IL- $4 \mathrm{R} \alpha$ exhibit impaired $\mathrm{T}_{\mathrm{H}} 2$ responses and IgE production, underscoring the role of IL-4 signaling in these processes. ${ }^{13.14}$ A second cytokine, interleukin 13 (IL-13), has biological activities that appear to be similar but not identical to those of IL-4. ${ }^{15-17}$ The IL-13 receptor is composed of IL-4R $\alpha$ and IL-13R $\alpha 1$ subunits. ${ }^{12,18}$ The importance of the IL- $4 \mathrm{R} \alpha$ subunit in both IL- 4 and IL-13 signaling in a mouse model of asthma has recently been demonstrated. ${ }^{19}$

Human $I L 4 R$ maps to $16 \mathrm{p} 11.2-16 \mathrm{p} 12.1$, a region associated with maternal inheritance of a gene that segregates with atopy. ${ }^{8,20}$ Six common human IL4R polymorphisms, which result in amino acid changes have been reported..$^{9,21-23}$ Two appear to be functionally significant, influencing IL-4 signaling and risk of atopy. The first variant, caused by a $G$ to $A$ transition at nucleotide 1902, results in the substitution of arginine for glutamine at amino acid 551 (Gln551Arg) in an intracellular domain. The Arg variant acts dominantly and is associated with 
atopy. ${ }^{9}$ The second variant is an A to $\mathrm{G}$ transition at nucleotide 398 which results in the substitution of valine for isoleucine at position 50 (Ile50 Val) in the extracellular domain. This Ile variant appears to act recessively and is associated with atopy and atopic asthma. ${ }^{10}$

In reports of these $I L 4 R$ variants to date, few individuals (for Gln551Arg)" or a restricted ethnic population (for Ile50Val) ${ }^{10.24}$ were examined for variant allele frequency. We report here significant differences in the allele frequencies of the Ile50Val and Gln551 Arg variants in four populations with different ethnic origins.

\section{MATERIALS AND METHODS}

\section{Specimen preparation}

Anonymous dried blood spots originating from the New York State Newborn Screening Program, which screens all infants born in the state, were randomly chosen and used as a genomic DNA source. Population groups were assigned using the race/ethnicity check-off completed at the birth hospital. Preparation of the template has been previously described. ${ }^{25}$ Briefly, 1-mm in diameter sized filter paper punches containing the dried blood were fixed in methanol and air-dried. An aliquot of sterile water was added to the specimens and they were capped, boiled for 10 minutes, cooled, and centrifuged. PCR mix was prepared and added directly to the tube containing the blood spot.

\section{PCR for Gin551Arg}

PCR primers for amplification of the 308 base pair IL4R Gln551Arg gene fragment were (IL4RAS1) 5' -CCG AAA TGT CCT CCA GCA TG-3' and (IL4RAS2) 5'-CCA GTC CAA AGG TGA ACA AGG GG-3'. Amplification reactions contained $200 \mu \mathrm{M}$ dNTPs, $1.5 \mathrm{mM} \mathrm{MgCl}_{2}, 0.4 \mu \mathrm{M}$ primers, and $1.25 \mathrm{U}$ Taq in $10 \mathrm{mM}$ Tris- $\mathrm{HCl}, \mathrm{pH} 8.3$, and $50 \mathrm{mM} \mathrm{KCl}$. After a 5-minute denaturation at $95^{\circ} \mathrm{C}, 30$ cycles were carried out as follows: $95^{\circ} \mathrm{C}$ denaturation for 1 minute, $63^{\circ} \mathrm{C}$ annealing for 1 minute, and $72^{\circ} \mathrm{C}$ polymerization for 2 minutes, followed by a final 5-minute polymerization step.

\section{Allele-specific oligonucleotide hybridization (Gln551Arg)}

Five $\mu \mathrm{L}$ of PCR products were spotted onto replicate $\mathrm{Hy}$ bond $\mathrm{N}+$ (Amersham, Arlington Heights, IL) or GeneScreen (NEN Life Science Products, Boston, MA) filters. The filters were air dried, and DNA was fixed in $0.4 \mathrm{~N} \mathrm{NaOH}$ after denaturation and neutralization according to the manufacturer's instructions. Probes for the Gln551Arg variant were end-labeled with $\gamma^{32} \mathrm{P}$-dATP using polynucleotide kinase (New England Biolabs, Beverly, MA). Sequences were (IL4RASP1) 5' GTG GCT ATC AGG AGT TTG-3' and (IL4RASP2) 5'-GTG GCT ATC GGG AGT TTG-3' for the Gln551 and Arg551 probes respectively. Filters were prehybridized for 45 minutes and hybridized for 2 hours at $56^{\circ} \mathrm{C}$ in $3 \mathrm{M}$ tetramethylammonium chloride (TMAC) hybridization buffer (3 M TMAC, $0.6 \% \mathrm{SDS}, 1 \mathrm{mM}$ EDTA, $5 \times$ Denhardt's reagent, $0.01 \mathrm{M}$ $(\mathrm{Na})_{3} \mathrm{PO}_{4}, \mathrm{pH} 6.8$, and $8 \mu \mathrm{g} / \mathrm{mL}$ herring sperm DNA, Sigma,
St. Louis, MO). Filters were washed in TMAC wash solution ( 3 M TMAC, $0.6 \%$ SDS, $10 \mathrm{mM}$ EDTA, and $0.1 \mathrm{M}(\mathrm{Na})_{3} \mathrm{PO}_{4}, \mathrm{pH}$ 6.8 ) at room temperature and then at the hybridization temperature for 20 minutes. Filters were exposed to X-0-Mat film (Eastman Kodak, Rochester, NY) 3 hours to overnight at $-70^{\circ} \mathrm{C}$ with intensifying screens.

\section{PCR of lle50Val}

To amplify the 157 base pair Ile50Val gene fragment, the PCR primers were 5 ' -CGG AAT TCC GAG GCC CAC ACG TGT-3' and 5' -CGC TGG GCT TGA AGG AG-3'. ${ }^{10}$ Amplification reactions contained $200 \mu \mathrm{M}$ dNTPs, $1.5 \mathrm{mM} \mathrm{MgCl}_{2}, 0.2$ $\mu \mathrm{M}$ primers, and $0.8 \mathrm{U}$ Taq in a 16:1 molar ratio of Taq-Start monoclonal antibody (Clontech, Palo Alto, CA) in $10 \mathrm{mM}$ Tris- $\mathrm{HCl}, \mathrm{pH} 8.3$, and $50 \mathrm{mM} \mathrm{KCl}$. After a 5-minute denaturation at $95^{\circ} \mathrm{C}, 30$ cycles were carried out as follows: $95^{\circ} \mathrm{C}$ denaturation for 30 seconds, $59^{\circ} \mathrm{C}$ annealing for 30 seconds, and $72^{\circ} \mathrm{C}$ polymerization for 30 seconds, followed by a final 5-minute polymerization step.

\section{Restriction endonuclease digestion (lle50Val)}

Ten $\mu \mathrm{L}$ of PCR product was digested with 5 units of Msl $\mathrm{I}^{10}$ (Promega Corp., Madison, WI) for 48 hours at $37^{\circ} \mathrm{C}$. The digested products were electrophoresed on a $3 \%$ NuSieve: $1 \% \mathrm{LE}$ agarose gel (FMC Bioproducts, Rockland, ME). In the presence of the Val50 allele, the 157 base pair product was digested to 137 and 20 base pair products. Products were visualized by ethidium bromide staining.

\section{Confirmation of control specimens}

For each possible genotype, representative specimens were sequenced using an ABI373 fluorescent sequencer by the Molecular Genetics Core Facility using the forward primer as the sequencing primer. Once confirmed, these served as positive controls for Arg551 and Val50 in these experiments.

\section{Statistical methods}

Pairwise comparisons of population-specific allele frequencies were performed by Fisher's exact test. ${ }^{26}$ Departures of observed allele frequencies from those predicted by Hardy-Weinberg equilibrium on the basis of population-specific variant allele totals were assessed with $\chi^{2}$ tests. ${ }^{27,28}$ Estimates of haplotype frequency and linkage disequilibrium were assessed by likelihood ratio tests. ${ }^{28}$

\section{RESULTS}

Specimens used for these studies were anonymously collected from the New York State Newborn Screening Program. Data were collected from 173 to 285 specimens for each ethnic group. The allele frequencies of the two IL4R variants were determined in four populations of differing ethnic origin. The results of these genotyping experiments are shown in Tables 1 and 2. 
Table 1

Interleukin-4 receptor $\alpha$ Gln551Arg polymorphism (A to $\mathrm{G}$ transition)

\begin{tabular}{|c|c|c|c|c|c|c|c|c|}
\hline \multicolumn{9}{|c|}{ Genotype Frequencies } \\
\hline \multirow{2}{*}{$\frac{\text { Population }}{\text { Genotype }}$} & \multirow{2}{*}{$\begin{array}{c}\text { No. of } \\
\text { Specimens (n) }\end{array}$} & \multicolumn{2}{|c|}{$\begin{array}{c}(\mathrm{AA}) \\
(\mathrm{G} \ln / \mathrm{G} \ln )\end{array}$} & \multicolumn{2}{|c|}{$\begin{array}{c}(\mathrm{AG}) \\
(\mathrm{Gln} / \mathrm{Arg})^{* *}\end{array}$} & \multicolumn{2}{|c|}{$\begin{array}{c}\text { (GG) } \\
(\text { Arg/Arg })^{\star *}\end{array}$} & \multirow{2}{*}{$\begin{array}{l}\text { Arg551** Allele } \\
\text { Frequency }(\%)\end{array}$} \\
\hline & & n & $\%$ & $\mathrm{n}$ & $\%$ & $\mathrm{n}$ & $\%$ & \\
\hline Black & 285 & 34 & 11.9 & 115 & 40.4 & 136 & 47.7 & 67.9 \\
\hline White & 188 & 117 & 62.2 & 66 & 35.1 & 5 & 2.7 & 20.2 \\
\hline Hispanic & 189 & 77 & 40.7 & 84 & 44.4 & 28 & 14.8 & 37.0 \\
\hline Asian & 190 & 118 & 62.1 & 66 & 34.7 & 6 & 3.2 & 20.5 \\
\hline
\end{tabular}

Allele frequency comparisons by Fisher's exact test: all comparisons significant at $p<0.0001$; except White vs. Asian.

Genotype comparisons by $3 \times 2$ Chi-Square: all comparisons significant at $p<0.002$; except White vs. Asian. **The Arg variant is associated with atopy. ${ }^{9}$ Numbering of amino acids is according to the sequence reported by Idzerda et al..$^{21}$ and does not include the signal peptide.

Table 2

Interleukin-4 receptor $\alpha$ Ile50Val polymorphism (A to G transition)

\begin{tabular}{|c|c|c|c|c|c|c|c|c|}
\hline \multicolumn{9}{|c|}{ Genotype Frequencies } \\
\hline \multirow{2}{*}{$\frac{\text { Population }}{\text { Genotype }}$} & \multirow{2}{*}{$\begin{array}{c}\text { No. of } \\
\text { Specimens }(n)\end{array}$} & \multicolumn{2}{|c|}{$\begin{array}{c}(\mathrm{AA}) \\
(\text { Ile/Ile })^{* *}\end{array}$} & \multicolumn{2}{|c|}{$\begin{array}{c}(\mathrm{AG}) \\
(\text { Ile/Val })^{* *}\end{array}$} & \multicolumn{2}{|c|}{$\begin{array}{c}(\mathrm{GG}) \\
(\mathrm{Val} / \mathrm{Val})\end{array}$} & \multirow{2}{*}{$\begin{array}{l}\text { Ile } 50^{* *} \text { Allele } \\
\text { Frequency (\% }\end{array}$} \\
\hline & & $n$ & $\%$ & $\mathrm{n}$ & $\%$ & $\mathrm{n}$ & $\%$ & \\
\hline Black & 261 & 101 & 38.7 & 93 & 35.6 & 67 & 25.7 & 56.6 \\
\hline White & 183 & 149 & 81.4 & 22 & 12.0 & 12 & 6.6 & 87.4 \\
\hline Hispanic & 188 & 112 & 59.6 & 59 & 31.4 & 17 & 9.0 & 75.1 \\
\hline Asian & 173 & 67 & 38.7 & 76 & 43.9 & 30 & 17.3 & 60.7 \\
\hline
\end{tabular}

Allele frequency comparisons by Fisher's exact test: all comparisons significant at $p<0.0001$; except Black vs. Asian.

Genotype frequency comparisons by $3 \times 2$ Chi-Square: all comparisons significant at $p<0.002$; except Black vs. Asian.

** The Ile variant is associated with atopy and atopic asthma. ${ }^{10}$ Numbering of amino acids is according to the sequence reported by Idzerda et al. ${ }^{21}$ and does not include the signal peptide.

\section{Polymorphism results}

The allele and the genotype frequencies for the Gln551Arg variant were the same in Whites and Asians (allele frequencies, $20.2 \%$ vs. $20.5 \%$ ). In agreement with this data, a frequency of $20 \%$ was recently reported for this polymorphism in a small population of control individuals of unreported ethnic background. ${ }^{9}$ Another recent study reported an allele frequency of $12 \%$ in Japanese controls who were not atopic or asthmatic. ${ }^{24}$
In the data reported here, Hispanics had a higher frequency of the Arg551 allele (37.0\%) than Whites and Asians. Overall, Blacks had the highest variant allele frequency $(67.9 \%)$ and almost half of these individuals were homozygous for the Arg551 allele (47.7\%).

Ile 50 was most common in Whites $(87.4 \%)$ followed by Hispanics (75.1\%), Asians (60.7\%), and Blacks (56.6\%). This recessively-acting allele is associated with overproduction of

Table 3 A

Interleukin-4 receptor $\alpha$ double homozygote frequencies

\begin{tabular}{|c|c|c|c|c|c|c|c|c|c|}
\hline \multirow[b]{2}{*}{ Population } & \multirow{2}{*}{$\begin{array}{c}\text { No. of } \\
\text { Specimens (n) }\end{array}$} & \multicolumn{2}{|c|}{$\begin{array}{l}\text { Ile/lle // } \\
\text { Gln/Gln }\end{array}$} & \multicolumn{2}{|c|}{$\begin{array}{l}\text { Ile/Ile // } \\
\text { Arg/Arg }\end{array}$} & \multicolumn{2}{|c|}{$\begin{array}{l}\mathrm{Val} / \mathrm{Val} / / \\
\mathrm{Gln} / \mathrm{Gln}\end{array}$} & \multicolumn{2}{|c|}{$\begin{array}{c}\mathrm{Val} / \mathrm{Val} / / \\
\mathrm{Arg} / \mathrm{Arg}\end{array}$} \\
\hline & & $\mathrm{n}$ & $\%$ & $\mathrm{n}$ & $\%$ & $\mathrm{n}$ & $\%$ & $\mathrm{n}$ & $\%$ \\
\hline Black & 261 & 11 & 4.2 & 60 & 23.0 & 12 & 4.6 & 27 & 10.3 \\
\hline White & 182 & 94 & 51.6 & 3 & 1.6 & 6 & 3.3 & 0 & 0.0 \\
\hline Hispanic & 186 & 47 & 25.3 & 16 & 8.6 & 7 & 3.8 & 2 & 1.1 \\
\hline Asian & 173 & 39 & 22.5 & 3 & 1.7 & 20 & 11.6 & 1 & 0.6 \\
\hline
\end{tabular}


Table 3B

$p$ values of double homozygote frequency comparisons

\begin{tabular}{lcccc}
\hline Populations & $\begin{array}{c}\text { Ile/Ile } / / \mathrm{Gln} / \mathrm{Gln} \\
(p \text { values })\end{array}$ & $\begin{array}{c}\text { Ile/Ile } / / \mathrm{Arg} / \mathrm{Arg} \\
(p \text { values })\end{array}$ & $\begin{array}{c}\text { Val/Val / Gln/Gln } \\
(p \text { values })\end{array}$ & $\begin{array}{c}\text { Val/Val } / / \mathrm{Arg} / \mathrm{Arg} \\
(p \text { values })\end{array}$ \\
\hline Black vs. White & 0.0000 & 0.0000 & 0.3355 & 0.0000 \\
Black vs. Hispanic & 0.0000 & 0.0000 & 0.4285 & 0.0000 \\
Black vs. Asian & 0.0000 & 0.0000 & 0.0062 & 0.0000 \\
White vs. Hispanic & 0.0000 & 0.0020 & 0.5162 & 0.2548 \\
White vs. Asian & 0.0000 & 0.6334 & 0.0023 & 0.4873 \\
Hispanic vs. Asian & 0.3156 & 0.0029 & 0.0043 & 0.5272 \\
\hline
\end{tabular}

both total and mite-specific IgE and atopic asthma in a Japanese population. ${ }^{10.24}$ The allele frequency for the Asian population reported here $(60.7 \%)$ differs from that reported for the control group in the studies of Mitsuyasu et al. ${ }^{10.24}$ (Ile50 allele frequencies of $40.4 \%$ and $41 \%$ ) in two regards. The Asian cohort studied here includes individuals from other ethnic groups in addition to those of Japanese descent. Furthermore, the anonymous nature of the blood spot specimens prohibits follow-up to determine what proportion of the genotyped individuals will develop atopy or asthma. Therefore, this New York State population also includes individuals who will develop asthma.

The Ile50 allele did not deviate from Hardy-Weinberg equilibrium in the Hispanic and Asian cohorts. However, the Ile50 allele was not in Hardy-Weinberg equilibrium in Blacks $\left(\chi^{2}=\right.$ 19.75, $P<0.001)$ or Whites $\left(\chi^{2}=37.55, P<0.0001\right) .{ }^{28}$ There are more homozygotes than expected by chance in both of these latter populations, suggesting that there has been some selective pressure for the "enhanced-activity" allele. No significant deviation from Hardy-Weinberg equilibrium was observed for the Gln551Arg variant.

Haplotypes were tested for linkage disequilibrium and a significant association was detected. Both polymorphisms (Ile/ Arg, IR) were found together more frequently in the Black cohort than would be expected by chance $(P=0.0113)$, even though the Ile50 allele was least frequent in this group. When the frequencies of double homozygotes (IleIle/ArgArg, II/RR) are compared, $23.0 \%$ of Blacks are II/RR (Table 3 ). This differs from the II/RR frequencies in Whites $(1.6 \%)$, Hispanics $(8.6 \%)$, and Asians $(1.7 \%)(P<0.00001)$. Hispanics are significantly different from Whites $(P=0.002)$ and Asians $(P=$ $0.0029)$ with respect to the frequency of II/RR.

\section{DISCUSSION}

This population-based allele-frequency study examined two $I L 4 R$ polymorphisms in four cohorts of specimens, which are unselected for disease. To date, little is known about the frequencies of these alleles in the general population. Previously, sample population demographics have not been well described $^{9,29}$ or were restricted to a single ethnic group. ${ }^{10,24}$ The studies reported here are important to consider when examin- ing the association of polymorphisms with disease using a limited number of control specimens. In addition to epidemiologic data supporting an association between Ile50 or Arg551 and risk of atopic asthma, influences of these variants on IL-4 receptor-mediated cellular responses to IL-4 have been described. 9,30 Both variants are associated with increased IL-4R signaling. The Arg551 allele appears to act dominantly because it has been shown to be associated with atopy in heterozygotes in one study population, but not in another. ${ }^{24}$ The Ile50 allele appears to be recessive. ${ }^{10}$

The data reported here show that both functional variants are present most frequently in Blacks and Hispanics. These groups may be prone to diseases related to increased IL-4 signaling and IgE production. For example asthma is most prevalent in Hispanics and Blacks. ${ }^{31}$ It is likely that the mechanism for asthma development may have different ethnic-specific genetic determinants. Evidence for this has recently been reported. ${ }^{2,32}$ At present, it is unknown whether possession of both "enhanced-activity" variants produces an additive or synergistic effect on IL-4R signaling in humans. A recent study that investigated a possible haplotype effect utilized transfected plasmids with combinations of the sequence variants in mouse $B$ cells after stimulation with murine or human IL-4. ${ }^{24}$ IL-4 binding was not affected by any of the constructs, but Ile50 was associated with increased IL-4R signaling. No augmentation of signaling above those increases observed in the presence of the Ile50 variant was evident in constructs containing the Arg551 allele. ${ }^{24} \mathrm{~A}$ second study that used transfected constructs carrying the Arg551 allele in mouse cells revealed no significantly altered signaling when the cells were stimulated with human IL-4. ${ }^{33}$

Whether these variant alleles truly play a role in the development of atopy, asthma, and other diseases remains a subject for further study. It is interesting that those alleles exerting an effect on IL-4R function exist at a high frequency in different populations. At some point in time, it may have been advantageous to have the capacity to mount a strong $\mathrm{T}_{\mathrm{H}} 2$ response to some endemic pathogen(s). IL-13 also plays a role in $\mathrm{T}_{\mathrm{H}} 2$ development and induces IgE synthesis in human B cells. ${ }^{15,16}$ Thus $I L 4 R$, polymorphisms may also influence IL-13 signaling and this effect may vary in different populations. To investigate this, further analysis of the two described $I L 4 R$ variants and the 
effects of other polymorphisms in this gene in atopic asthmatics from these same ethnic groups are ongoing.

\section{Acknowledgments}

The authors thank the Molecular Genetics Core Facility at the Wadsworth Center for sequence analysis of variants and the synthesis of oligonucleotides and the Computational Biology and Statistics Core for computing hardware and statistical analyses. This work was supported by the New York State Department of Health.

\section{References}

1. Marsh DG. Neely ID, Breazeale DR, Ghosh B, Friedhoff LR, Ehrlich-Kautzky E Schou C, Krishnaswamy G, Beaty TH. Linkage analysis of IL4 and other chromosome 5 q 31.1 markers and total serum immunoglobulin E concentrations. Science 1994:264:1152-1156.

2. The Collaborative Study on the Genetics of Asthma (CSGA). A genome-wide search for asthma susceptibility loci in ethnically diverse populations. Nat Genet 1997;15: $389-392$

3. Daniels SE, Bhattacharrya S, James A, Leaves NI, Young A, Hill MR, Faux JA, Ryan GF, le Souef PN, Lathrop GM, Musk AW, Cookson WO. A genome-wide search for quantitative trait loci underlying asthma. Nature 1996:383:247-250.

4. Palmer LJ, Daniels SE, Rye PJ, Gibson NA, Tay GK, Cookson WO, Goldblatt J, Burton PR, LeSouef PN. Linkage of chromosome $5 q$ and $11 \mathrm{q}$ gene markers to asthma-associated quantitative traits in Australian children. Am / Respir Crit Care Med 1998:158:1825-1830

5. Postma DS, Bleecker ER, Amelung PJ, Holroyd KJ, Xu J, Panhuysen CIM, Meyers DA, Levitt RC. Genetic susceptibility to asthma-bronchial hyperresponsiveness coinherited with a major gene for atopy. N Engl I Med 1995;333:894-900.

6. Rosenwasser LJ, Klemm DJ, Dresback IK, Inamura H, Mascali JJ, Klinnert M, Borish L. Promoter polymorphisms in the chromosome 5 gene cluster in asthma and atopy. Clin Exp Allergy 1995;25(Suppl):74-78.

7. Song Z, Casolaro V, Chen R, Georas SN, Monos D, Ono SI. Polymorphic nucleo tides within the human $\mathrm{IL}-4$ promoter that mediate overexpression of the gene. J Immunol 1996;156:424-429.

8. Deichmann KA, Henizmann A, Forster J, Dischinger S, Mehl C, Brueggenolte E, Hildebrandt $F$, Moseler $M$, Kuehr J. Linkage and allelic association of atopy and markers flanking the IL4-receptor gene. Clin Exp Allergy 1998:28:151-155.

9. Hershey GIT, Friedrich MF, Esswein LA, Thomas ML, Chatila TA. The association of atopy with a gain-of-function mutation in the $\alpha$ subunit of the interleukin- 4 receptor. N Engl J Med 1997;337:1720-1725.

10. Mitsuyasu H, Izuhara K, Mao XQ, Gao PS, Arinobu Y, Enomoto T, Kawai M, Sasaki S, Dake Y, Hamasaki N, Shirakawa T, Hopkin JM. Ile50Val variant of IL-4R $\alpha$ upregulates IgE synthesis and associates with atopic asthma. Nat Genet 1998;19:119_ 120

11. Murata T, Taguchi J, Puri RK. Interleukin-13 receptor $\alpha^{\prime}$ but not $\alpha$ chain: a functional component of interleukin-4 receptors: Blood 1998;91:3884-3891.

12. Miloux B, Laurent P, Bonnin O, Lupker I, Caput D, Vita N, Ferrara P. Cloning of the human IL13-R $\alpha$ l chain and reconstitution with the IL-4R $\alpha$ of a functional IL-4/ IL-13 receptor complex. FEBS Lett 1997;401:163-166.

13. Kopf M, LeGros G, Bachmann M, Lamers MC, Bluethmann H, Kohler G. Disruption of the murine IL-4 gene blocks $\mathrm{T}_{\mathrm{H}} 2$ cytokine responses. Nature 1993;362:245248.
14. Noben-Trauth N, Shultz LD, Brombacher F, Urban, Jr. JF, Gu H, Paul WE. An interleukin 4 (IL-4)-independent pathway for CD4 + T cell IL-4 production is revealed in IL.4 receptor-deficient mice. Proc Natl Acad Sit, USA 1997;94:1083810843 .

15. Zurawski G, deVries JE. Interleukin 13, an interleukin 4-like cytokine that acts on monocytes and B cells, but not on T cells. Immunol Today 1994:15:19-26.

16. McKenzie GJ, Emson CL, Bell SE, Anderson S, Fallon P, Zurawski G, Murray R, Grencis $R$, McKenzic AN. Impaired development of $T_{H^{2}}$ cells in IL-13-deficient mice. Immunity 1998;9:423-432.

17. Wills-Karp M, Luyimbazi J, Xu X, Schofield B, Neben TY, Karp CL. Interleukin-13: Central mediator of allergic asthma. Science 1998; 282:2258-2261.

18. Aman MI, Tayebi N, Obiri NI, Puri RK, Modi WS, Leonard WI. cDNA cloning and characterization of the human interleukin 13 receptor alpha chain. J Biol Chem 1996:271:29265-29270?.

19. Grunig G, Warnock M, Wakil AE, Venkayya R, Brombacher F, Rennick DM, Sheppard D, Mohrs M, Donaldson DD, Locksley RM, Corry DB. Requirement for IL-13 independently of IL-4 in experimental asthma. Science 1998;282:2261-2263.

20. Pritchard MA, Baker E, Whitmore SA, Sutherland GR, Idzerda RL, Park LS, Cosman D, Jenkins NA, Gilbert DI, Copeland NG, Beckman P. The interleukin-4 receptor gene (IL4R) maps to 16p11.2-16p I2.1 in human and to the distal region of mouse chromosome 7. Genomics 1991:10:801-806.

21. Idzerda RL, March CI, Mosley B, Lyman SD, Vanden Bos T, Gimpel SD, Din WS, Grabstein KH, Widmer MB, Park LS, Cosman D, Beckman P. Human interleukin 4 receptor confers biological responsiveness and defines a novel receptor superfamily. J Exp Med 1990;171:861-873.

22. Galizzi I-P, Zuber CE, Harada N, Gorman DM, Djossou O, Kastelein R, Banchereau I. Howard M. Miyajima A. Molecular cloning of a CDNA encoding the human interleukin 4 receptor. Int Immunol 1990;2:669-675.

23. Deichmann K. Bardutzky J, Forster J, Heinzmann A, Kuehr J. Common polymorphisms in the coding part of the IL-4 gene. Biochem Biophys Res Commun 1997:231: 696-697.

24. Mitsuyasu H, Yanagihara Y, Mao X-Q, Gao P-S, Arinobu Y, Ihara K, Takabayashi A, Hara T, Enomoto T, Sasaki S, Kawai M, Hamasaki N, Shirakawa T, Hopkin IM, Izuhara K. Cutting edge: Dominant effect of Ile50Val variant of the human IL-4 receptor alpha-chain in IgE synthesis. JImmunol 1999;162:1227-1231.

25. Caggana M, Conroy JM, Pass KA. Rapid, efficient method for multiplex amplification from filter paper. Hum Mutat 1998;1 1:404-409.

26. Fisher RA. The logic of inductive inference. J Roy Stat Soc 1935;98:39-54.

27. Pearson $K$. On the theory of contingency and its relation to association and normal correlation, Cambridge, England: Cambridge University Press, 1904

28. Terwilliger JD, Ott J. Handbook of human genetic linkage. Baltimore: Johns Hopkins University Press, 1994;199-210, 277-279.

29. Grimbacher B, Holland SM, Puck JM. The interleukin-4 receptor variant Q576R in hyper-IgE syndrome. N Engl J Med 1998;338:1073-1074.

30. Yi T, Mui AL, Krystal G, Ihle IN. Hematopoietic cell phosphatase associates with the interleukin-3 (IL-3) receptor beta chain and down-regulates IL-3-induced tyrosine phosphorylation and mitogenesis. Molec Cell Biol 1993;13:7577-7586.

31. Carter-Pokras OD, Gergen PJ. Reported asthma among Puerto Rican, MexicanAmerican, and Cuban children: 1982-1984. Am J Public Health 1993;83:580-582.

32. Ober C, Cox NJ, Abney M, DiRienzo A, Lander ES, Changvaleket B, Gidley H, Kurtz B, Lee J, Nance M, Pettersson A, Prescott J, Richardson A, Schlenker E, Summerhill E, Willadsen S, Parry R. Genome-wide search for asthma susceptibility loci in a founder population. Hum.Molec Genet 1998;9:1393-1398.

33. Yang HY, Shelburne CP, Zamorano I, Kelly AE, Ryan IJ, Keegan AD. Cutting edge: Effects of an allergy-associated mutation in the human IL-4R $\alpha$ (Q576R) on human IL-4-induced signal transduction. / Immunol 1999;162:4385-4389. 